\title{
GENDER DIFFERENCES IN SEMANTIC FLUENCY PATTERNS IN CHILDREN
}

Federico Soriano

federicogonzalosoriano@gmail.com

Institute of Translational and Cognitive Neuroscience (ITCN), Argentina

Julieta Fumagalli

fumagallijulieta@gmail.com

Diego Shalom

diego.shalom@gmail.com

Juan Pablo Barreyro

jpbarreyro@gmail.com

Macarena Martínez-Cuitiño

mariamacarenamartinez@gmail.com

National Scientific and Technical Research Council (CONICET), Argentina

Received November 14, 2016; Revised December 18, 2016; Accepted December 21, 2016

\begin{abstract}
Previous literature in cognitive psychology has provided data involving differences in language processing between men and women. It has been found that women are usually more proficient with certain semantic categories such as fruit, vegetables and furniture. Men are reported to be better at other categories semantic, e.g. tools and transport. The aim of this article is to provide an inquiry about possible differences in semantic category processing of living things (LT) and inanimate objects (IO) by Argentinian Spanish-speakers school-aged children. The group of 86 children between 8 and 12 years old (51.16\% boys) has been assessed on a semantic fluency task. Six semantic categories have been tested, three of them from the LT domain (animals, fruit/vegetables, and body parts) and three from the IO domain (transport, clothes and musical instruments). Results showed differences in semantic processing between boys and girls. Girls retrieved more items from the LT domain and activated more animals and fruit/vegetables. These findings appear to support an innate conceptual organization of the mind, which is presumably influenced by cultural factors and/or schooling.
\end{abstract}

Keywords: school-age children, gender differences, semantic processing, living things, inanimate objects

Соріано Федеріко, Фумагалі Джуліета, Дісго Шалом Дісго, Барейра Хуан Пабло, Мартінез-Квітіньо Макарена. Семантична біжучість та гендерні відмінності серед дітей.

Анотація. Згідно з даними досліджень у галузі когнітивної психології, існують відмінності в переробленні мовних даних чоловіками та жінками. Виявлено, що жінки, як правило, більш вправні в певних семантичних категоріях, як-от: фрукти, овочі та меблі. Чоловіки ж краще за жінок орієнтуються в таких семантичних категоріях: інструменти та

(C) Soriano, Federico; Fumagalli, Julieta; Shalom, Diego; Barreyro, Juan Pablo; Martínez-Cuitiño, Macarena. (2016). East European Journal of Psycholinguistics, 3(2), 92-102. DOI: 10.5281/zenodo.267879 
транспорт. У статті йдеться про експеримент, який проведено серед аргентинських дітей носіїв іспанської мови, що полягав у визначенні можливих гендерних відмінностей під час виконання завдання на семантичну біжучість, а саме в категоріях з розряду істот та неістот. В експерименті взяла участь група 386 дітей віком від 8 до 12 років (51,16 \% хлопчиків), яким було запропоновано шість семантичних категорій, три 3 яких із розряду істот (тварини, фрукти/овочі, частини тіла), та три з розряду неістот (транспорт, одяг та музичні інструменти). Було зафіксовано генедрні відмінності у виконанні мовних завдань на основі різних семантичних категорій. Респонденти жіночої статі надали більшу кількість слів у категоріях істот, а саме: тварин, фруктів та овочів. Одержані дані засвідчують вроджену концептуальну організацію розуму, на який, імовірно, здатні впливати культурні чинники i/або навчання.

Ключові слова: діти шкільного віку, гендерні відмінності, семантична обробка, живі істоти, неістоти.

\section{Introduction}

Lexical retrieval mechanisms are a widely studied topic in neuropsychological research (REF.). Children's and adults' performances in fluency tasks (FT) have shed light on the mental processes that underlie linguistic behaviour (REF). Semantic fluency tasks (SFT) reveal how people recover lexical items belonging to specific categories within a fixed amount of time. The search process active in such tasks requires direct access to the categories or subcategories stored in long-term memory (Spreen \& Strauss, 1998). The semantic memory system, as first described by Tulving (1972), stores both concrete and abstract concepts. Among concrete concepts, different authors have identified differential processing for living things (animals, fruit, vegetables and body parts) versus inanimate objects (tools, utensils, means of transport, etc.).

A more recent area of research has focused on identifying potential differences in semantic processing between the genders. Several studies have shown that men and women respond differently to certain semantic categories (Albanese et al., 2000; Barbarotto et al., 2008; Capitani et al., 1999; Gainotti et al., 2012; Laws, 1999, 2000, 2004, Moreno-Martínez \& Moratilla-Pérez, 2016). While gender by category interaction is commonly accepted, there is currently no consensus regarding which categories present advantages for either gender. Traditional studies claim that women have showed an advantage in the retrieval of living things (LT), while men perform better with inanimate objects (IO). However, several studies suggest that gender differences may reflect advantages for specific categories or subcategories rather than different semantic domains (Gainotti et al., 2012; Laws, 1999, 2000, 2004). While plants, fruit and vegetables (LT) as well as furniture (IO) have been associated with an advantage for women, means of transport and tools (IO) have been associated with a male advantage. At the same time some studies have attributed an advantage for processing animals (LT) to men, others have associated the advantage with women (Albanese et al., 2000; Barbarotto et al., 2008; Laws, 2004; McKenna \& Parry, 1994; Moreno-Martínez \& Moratilla-Pérez, 2016, Soriano et al., 2015).

The source of controversy surrounding these matters concerns the origin of the category discrepancies. The studies conducted on this subject can be categorized 
into two broad theoretical frameworks. According to the Domain-Specific Hypothesis (DSH) (Capitani et al., 2003; Caramazza \& Mahon, 2003, 2006; Caramazza \& Shelton, 1998; Mahon \& Caramazza, 2003), gender-specific advantages for one category versus another are the result of stronger connections in cortical areas where those categories are processed. The stronger connections are thought to be innate and to have arisen due to natural selection processes that are associated with one gender versus the other. By contrast, other authors (Gainotti, 2005; Gainotti et al., 2012; Gerlach \& Gainotti, 2016; Marr et al., 2007) propose that advantages for one category over the other are a result of individual world experiences. Hence, differences in categorical processing are culturally-determined (as opposed to biologically-determined), which means that men's and women's social roles in different cultures could directly affect the conceptual organization in their brains. This would also imply that differences in female and male social roles across generations within the same culture could also affect conceptual architecture (Gainotti, 2005; Gerlach \& Gainotti, 2016; Laiacona et al., 2006; Laws, 2000, 2004; Marra et al., 2007).

Considering the aforementioned studies, it would be relevant to inquire about possible discrepancies in semantic processing made by different-aged children. By examining boys' and girls' performance in SFT, qualitative and quantitative differences in diverse stages of semantic memory storage could be uncovered. Theoretically, if the same differences observed in grown-ups were to be identified in children at a very early age, this could support the notion of biologically determined conceptual processing. Barbarotto et al. (2008) have evaluated a group of 202 Italian children between 3-5 year-old using a coloured picture-naming task including items from six semantic categories and compared their performance to a group of 48 adults. While men and boys were faster than women and girls at naming "means of transport" and "tools", women (but not girls) were relatively faster at naming "fruit and vegetables". The post-hoc analysis showed that both boys and girls improved their performance with the increase of age, accounting for a wider and richer semantic repertoire. While some studies found significantly better semantic fluency in Argentinian as well as Spanish boys (Marino et al., 2011; Marino \& Díaz-Fajreldines, 2011), most studies conducted across different languages do not report gender-based categorical dissociations in SFT (Hurks et al., 2006; John \& Rajashekhar, 2014; Koren et al., 2005; Lozano Guitiérrez \& Ostrosky-Solís, 2006; Nieto et al., 2008; Riva et al., 2000; Leite et al., 2016; Martínez-Cuitiño et al., 2014). However, it is important to point out that most studies about semantic fluency in children do not consider gender as a relevant variable. Those studies usually focus on age differences (Casals-Coll et al., 2013; Lozano Gutiérrez \& Ostrosky-Solís, 2006; Pekkala et al., 2009), comparison between languages (Olabarrieta Landa et al., 2015) or between tasks (Fumagalli, Soriano, Barreyro \& Martínez-Cuitiño, in press).

The aim of the present study is to investigate potential age- and/or genderbased differences in semantic processing by domain as well as by category in a group of Argentinian school-aged children. 


\section{Methods}

Participants. A total of 86 native speakers of Argentinian Spanish participated in this study. These included $323^{\text {rd }}$ grade children (M age: 8 years, 6 months; 59.4 $\%$ female), $255^{\text {th }}$ grade children (M age: 12 years, 7 months; $60 \%$ female), and 29 $7^{\text {th }}$ grade children ( $\mathrm{M}$ age: 12 years, 7 months; $60 \%$ female). None of the participants had sensory deficits, learning disorders or neurological alterations at the time of evaluation. All of the participants attended a middle class school in the city of Buenos Aires. Parents were appropriately informed about the study and signed a consent form indicating their voluntary participation in the experiment.

Materials and Procedure. All of the participants were tested in a single session by one researcher during school hours. The testing procedure took place in a room at the school. Children answered an SFT and were given the following instructions: "I am going to ask you to tell me, within one minute, as many words as you can for each category I say, for example, 'professions' ". They were asked to produce items for three categories from the LT domain (animals, fruit and vegetables, and body parts), and three categories from the IO domain (clothes, musical instruments and means of transport). A practice trial was conducted with two additional categories (sports and professions) to ensure children understood the study instructions.

Answers were recorded using a digital device and transcribed onto a database by a different researcher afterwards. A third researcher checked the database for possible mistakes in the transcription.

Valid responses were those referring to different items within each category. When two words refer to the same concept, such as chancho and cerdo (both words meaning 'pig'), the second word produced was deleted. Superordinate answers (i.e. birds, fish) were not accepted. Different variants for the same concept were unified (sports car was counted as car). Finally, words that did not belong to the specific category and repeated words were also eliminated. All answers were checked by three different researchers who discussed each case whenever discrepancies arose.

Statistical analysis. In order to study possible differences between semantic domain (LT vs. IO), gender and grade $\left(3^{\text {rd }}, 5^{\text {th }}\right.$ and $7^{\text {th }}$ ), a three-way mixed ANOVA was performed, using semantic domain as factor for within-subject variability and gender and grade as factors for across-subject variability. Next, a post-hoc Sidak analysis based on partial Eta squared $\left(\eta^{2}\right)$ was conducted. Then, a second $6 \times 2 \times 3$ mixed ANOVA analysis was conducted with semantic category (animals, fruit and vegetables, body parts, musical instruments, clothes and means of transport) as a within-subject variable and gender and school grade as across-subject variables. A post-hoc Sidak analysis was then calculated for each variable and interaction, and the effect size was based on partial Eta squared $\left(\eta^{2}\right)$.

\section{Results}

The aim of the current study was to investigate possible differences and interactions between semantic domains (LT and IO), gender and grade $\left(3^{\text {rd }}, 5^{\text {th }}\right.$ and $7^{\text {th }}$ ) in a SFT. Table 1 provides the descriptive statistics of the results. 
Table 1

Descriptive statistics for semantic domains, gender and grade

\begin{tabular}{|c|c|c|c|c|c|}
\hline \multirow{2}{*}{ Grade } & & \multicolumn{2}{|l|}{ LT } & \multicolumn{2}{|l|}{ IO } \\
\hline & & $\mathrm{M}$ & SD & $\mathrm{M}$ & SD \\
\hline \multirow[t]{2}{*}{$3^{\text {rd }}$} & Boys $(\mathrm{n}=13)$ & 36.38 & 5.28 & 25.08 & 6.08 \\
\hline & Girls $(\mathrm{n}=19)$ & 41.63 & 7.51 & 29.16 & 5.62 \\
\hline \multirow[t]{2}{*}{$5^{\text {th }}$} & Boys $(\mathrm{n}=15)$ & 44.20 & 9.11 & 29.53 & 5.05 \\
\hline & Girls $(\mathrm{n}=10)$ & 51.90 & 9.79 & 33.40 & 8.80 \\
\hline \multirow[t]{2}{*}{$7^{\text {th }}$} & Boys $(\mathrm{n}=16)$ & 47.00 & 5.67 & 31.00 & 4.53 \\
\hline & Girls $(n=13)$ & 54.62 & 12.53 & 32.69 & 7.36 \\
\hline
\end{tabular}

The statistical analysis revealed the main effect of semantic domain $\left(\mathrm{F}_{(1,80)}=\right.$ $\left.351.64, p<.001, \eta^{2}=.82\right)$ : overall, children produced significantly more words from the $\mathrm{LT}$ domain $(\mathrm{M}=45.96, \mathrm{SD}=10.09)$ than from the $\mathrm{IO}$ domain $(\mathrm{M}=30.14$, $\mathrm{SD}=6.49)$. We also observed a main effect of gender $\left(\mathrm{F}_{(1,80)}=13.05, p=.001, \eta^{2}=\right.$ $.14)$, with girls retrieving a significantly higher number of items than boys, overall (girls: $\mathrm{M}=40.57, \mathrm{SD}=6.88$; boys: $\mathrm{M}=35.53, \mathrm{SD}=9.22$ ). There was also a main effect of grade $\left(\mathrm{F}_{(2,80)}=14.24, p<.001, \eta^{2}=.26\right)$. Post-hoc analyses showed significant differences $(p=.001)$ between $3^{\text {rd }}$ grade $(\mathrm{M}=33.03, \mathrm{SD}=6.58)$ and $5^{\text {th }}$ grade $(M=39.76, S D=8.43)$ and between $3^{\text {rd }}$ and $7^{\text {th }}$ grade $(M=41.33, S D=7.94)$, but no differences between $5^{\text {th }}$ and $7^{\text {th }}$ grade were found.

There was also a significant interaction between semantic domain and grade $\left(\mathrm{F}_{(2,80)}=6.57, p=.002, \eta^{2}=.14\right)$. There was a significant effect for LT in every grade $(p<.01)$. There were also significant differences $(p<.05)$ between $3^{\text {rd }}$ grade $(\mathrm{M}=39.01, \mathrm{SD}=1.53)$ and $5^{\text {th }}$ grade $(\mathrm{M}=48.05, \mathrm{SD}=1.73)$ and between $3^{\text {rd }}$ and $7^{\text {th }}$ grade $(\mathrm{M}=50.81, \mathrm{SD}=1.58)$. However, there were no significant differences between $5^{\text {th }}$ and $7^{\text {th }}$ grades. For IO, we only observed significant differences $(p<.05)$ between the $3^{\text {rd }}$ grade $(\mathrm{M}=27.12, \mathrm{SD}=1.11)$ and $7^{\text {th }}$ grade $(\mathrm{M}=31.85$, $\mathrm{SD}=1.15)$, while $5^{\text {th }}$ grade $(\mathrm{M}=31.47, \mathrm{SD}=1.26)$ did not differ neither from $3^{\text {rd }}$ nor $7^{\text {th }}$ grade.

There was also an interaction between semantic domain and gender $\left(\mathrm{F}_{(1,80)}=\right.$ 4.66, $p=.03, \eta^{2}=.06$ ). Post-hoc analyses revealed that both boys and girls produced significantly more LT items $(p<.01)$ than IO, and that girls, in turn, produced more $\mathrm{LT}$ items $(\mathrm{M}=49.38, \mathrm{SD}=1.35)$ than boys $(\mathrm{M}=42.53, \mathrm{SD}=1.28)$. By contrast, there were no differences between gender for retrieval of IO items (girls: $\mathrm{M}=31.73, \mathrm{SD}=0.98$ and boys: $\mathrm{M}=28.54, \mathrm{SD}=0.93$ ).

Finally, there were no interactions between gender and grade $\left(\mathrm{F}_{(2,80)}=0.07\right.$, $\left.p=.94, \eta^{2}=.00\right)$ or between domain, gender and grade $\left(\mathrm{F}_{(2,80)}=.72, p=.49\right.$, $\eta^{2}=.02$ ).

The second aim of our study was to investigate possible differences and interactions between semantic categories, gender and grade in the SFT. Descriptive results are listed in Table 2. 
Table 2

Descriptive results for category, gender and grade

\begin{tabular}{|c|c|c|c|c|c|c|c|c|c|c|c|c|c|}
\hline \multirow[t]{2}{*}{ Grade } & \multirow[t]{2}{*}{ Gender } & \multicolumn{2}{|c|}{ Animals } & \multicolumn{2}{|c|}{$\begin{array}{l}\text { Fruit/ } \\
\text { Vegetables }\end{array}$} & \multicolumn{2}{|c|}{ Body Parts } & \multicolumn{2}{|c|}{$\begin{array}{l}\text { Musical } \\
\text { Instruments }\end{array}$} & \multicolumn{2}{|c|}{$\begin{array}{l}\text { Means of } \\
\text { transport }\end{array}$} & \multicolumn{2}{|c|}{ Clothes } \\
\hline & & $M$ & SD & $\mathrm{M}$ & SD & $\mathrm{M}$ & SD & $M$ & SD & $M$ & SD & $\mathrm{M}$ & SD \\
\hline \multirow[t]{2}{*}{$3^{\text {rd }}$} & $\begin{array}{l}\text { Boys } \\
(\mathrm{N}=13)\end{array}$ & 13.62 & 2.60 & 9.31 & 2.69 & 13.46 & 3.13 & 7.31 & 2.39 & 8.00 & 2.45 & 9.77 & 3.49 \\
\hline & $\begin{array}{l}\text { Girls } \\
(\mathrm{N}=19)\end{array}$ & 15.53 & 3.10 & 10.74 & 1.79 & 15.37 & 4.56 & 7.79 & 1.62 & 8.84 & 2.93 & 12.53 & 3.22 \\
\hline \multirow[t]{2}{*}{$5^{\text {th }}$} & $\begin{array}{l}\text { Boys } \\
(\mathrm{N}=15)\end{array}$ & 16.10 & 3.94 & 11.80 & 2.83 & 16.33 & 3.66 & 8.27 & 2.15 & 10.20 & 1.93 & 11.10 & 3.88 \\
\hline & $\begin{array}{l}\text { Girls } \\
(\mathrm{N}=10)\end{array}$ & 20.20 & 4.69 & 13.50 & 2.68 & 18.20 & 4.10 & 9.80 & 3.33 & 11.70 & 3.33 & 11.90 & 4.04 \\
\hline \multirow[t]{2}{*}{$7^{\text {th }}$} & $\begin{array}{l}\text { Boys } \\
(\mathrm{N}=16)\end{array}$ & 5.37 & 3.28 & 12.56 & 2.34 & 18.06 & 3.70 & 8.75 & 1.98 & 10.38 & 1.89 & 11.87 & 3.36 \\
\hline & $\begin{array}{l}\text { Girls } \\
(\mathrm{N}=13)\end{array}$ & 20.08 & 6.50 & 15.08 & 3.09 & 19.46 & 6.17 & 8.92 & 2.43 & 9.54 & 2.57 & 14.23 & 4.62 \\
\hline
\end{tabular}

The second statistical analysis revealed the main effect of semantic category $\left(\mathrm{F}_{(5,400)}=127.34, p<.001, \eta^{2}=.61\right)$. As a group, participants produced the most items for the category animals $(\mathrm{M}=16.97, \mathrm{DE}=.45)$, and the least for the category musical instruments $(\mathrm{M}=8.47, \mathrm{DE}=.25)$. There was also a main effect of gender $\left(\mathrm{F}_{(1,80)}=13.05, p=.01, \eta^{2}=.14\right)$, with girls producing significantly more items $(\mathrm{M}=13.52, \mathrm{DE}=.34)$ than boys $(\mathrm{M}=11.84, \mathrm{DE}=.32)$. There was also a main effect of grade $\left(\mathrm{F}_{(2,80)}=14.24, p<.001, \eta^{2}=.26\right)$. Post-hoc analyses showed significant differences $(p=.001)$ between $3^{\text {rd }}(\mathrm{M}=11.02, \mathrm{DE}=.38)$ and $5^{\text {th }}$ grade $(\mathrm{M}=13.25, \mathrm{DE}=.43)$ and between $3^{\text {rd }}$ and $7^{\text {th }}$ grade $(\mathrm{M}=13.77, \mathrm{DE}=.39)$, but no difference between $5^{\text {th }}$ and $7^{\text {th }}$ grade $(p=.75)$. Results for category by gender and grade are presented in Table 2.

There was a significant category by grade interaction $\left(\mathrm{F}_{(10,400)}=2.42, \mathrm{p}=.01\right.$, $\left.\eta^{2}=.05\right)$. Significant differences were observed for animals, fruit/vegetables and musical instruments between $3^{\text {rd }}$ and $5^{\text {th }}$ grade $(p<.05)$ and for animals, fruit/vegetables and body parts between $3^{\text {rd }}$ and $7^{\text {th }}$ grade $(p<.05)$. There were no significant interactions between $5^{\text {th }}$ and $7^{\text {th }}$ grade.

There was also a significant category by gender interaction $\left(\mathrm{F}_{(5,400)}=2.47, p<\right.$ $.05, \eta^{2}=.03$ ), which revealed that girls produced more items for animals and for fruit/vegetables than boys.

Finally, the three-way interaction of semantic category by gender by grade did not reach significance $\left(\mathrm{F}_{(10,400)}=0.76, p=.67, \eta^{2}=.02\right)$.

\section{Discussion}

The aim of the current study was to identify possible semantic processing dissociations between school aged boys and girls using a SFT. For over 20 years, 
authors have reported that men and women show differences in semantic processing (Gainotti et al., 2010; Laiacona et al., 2006; Laws, 1999, 2000, 2004; Marra et al., 2007). Most commonly, women have better performance in naming tasks and SFT for several categories: fruit and vegetables (LT) and furniture (IO). On the other hand, men have an advantage for tools and means of transport (IO). Most studies involving children have not assessed gender differences in SFT (John \& Rajashekhar, 2014; Koren, et al., 2005; Lozano Guitiérrez \& Ostrosky-Solís, 2006; Nieto, et al., 2008; Riva, et al., 2000). However, Barbarotto et al. (2008) tested Italian native speakers (adults and children) and found that boys performed better than girls at naming tools and means of transport, and girls did not show advantage for any of the categories tested. When adults were assessed, men showed a similar pattern as boys, and the women performed better than men at naming fruit/vegetables.

Marino et al. (2011) evaluated children between 8 and 12 years-old and Marino and Díaz-Fajreldines (2011) evaluated children between 8 and 14 years-old and in both researches found an advantage for animals in favour of boys.

The data collected in our investigation, with respect to semantic domain, showed that participants from all three grades tested retrieved more items from LT domain. On the other hand, it was also found that girls activated more items than boys do in the LT domain while there is no significant difference on the amount of IO boys and girls produced.

Regarding the participant's school grades, results indicated that for LT items, $3^{\text {rd }}$ grade participants named fewer items than $5^{\text {th }}$ and $7^{\text {th }}$ graders, while a significant difference in naming IO items was observed only between $3^{\text {rd }}$ and $7^{\text {th }}$ graders.

When looking into category sematic processing, girls produced more items for animals and fruit/vegetables than boys. This difference was detected between $3^{\text {rd }}$ and $5^{\text {th }}$ grade and between $3^{\text {rd }}$ and $7^{\text {th }}$ grade. These data are in line with findings by Soriano et al. (2015) who reported an advantage for those categories among women in a group of young adults from the same region. Also similar to our research, the adults in that study produced significantly more items from the LT domain. In addition, they found a better women performance for animals and vegetal items (fruit and vegetables).

The children in our study showed a strong gender effect in semantic processing in favour of women. These findings differ from data found in previous studies. Unlike Barbarotto et al. (2008), we did not observe a male advantage for any categories from the IO domain. Furthermore, girls showed an advantage for the category animals, which has previously yielded conflicting results. Our findings are also in contrast with findings by Marino and Diaz-Fajereldines (2011), who also tested a group of Argentinian children.

In order to be able to make a contribution to the discussion aforementioned regarding the origin of these distinguishing semantic processing between men and women it is necessary to do a more detailed analysis of our findings, considering the different hypothesis. Our data do not entirely support the DSH (Caramazza \& Mahon, 2003; Caramazza \& Shelton, 1998; Mahon \& Caramazza, 2003). According 
to DSH, we should have observed a male advantage for the category animals, as this would reflect the stronger role of males in hunting activities throughout history. Although gender differences found in this research are identical to those described for sample of young adults belonging to the same population (Soriano, et al., 2015) the advantage for the category of animals should have been spotted for boys and not girls as reported.

Our data do not support an experience-based hypothesis (Gainotti, et al., 2010; Gainotti, et al., 2012; Marra, et al., 2007), since gender-based dissociations are observed as early as childhood and remain throughout life. It should be noted that many traditional gender roles have been mostly lost over the last few decades in modern Western societies. For example, hunting is no longer essential to obtain food, and traditionally female activities such as cooking are practiced by both men and women, for hobby or as a career. This would lead us to think that gender by category interactions, as the ones reported by our study, could no longer be spotted. Some studies report that gender differences in language processing are only observed in older adults. Moreno-Martínez et al. (2008) identified statistical dissociations were only present in a sample of elder adults for the categories of flowers, vegetables and utensils in favour of women and musical instruments in favour of men.

As suggested by Gainotti (2015), identifying whether gender differences are a result of innate or experience-dependent factors is not easy. The current work has some limitations that should be pointed out. Firstly, the fact that participants had some level of schooling implies that their prior semantic knowledge could have been modified. A possible way to overcome this limitation could be widening our sample, including younger boys and girls, who have not yet started any formal education process. Even though this could add more information on children semantic processing, working with a younger population not necessarily guarantees shedding light over the main discussion: do humans have an innate distinguishing semantic processing?

A second possible limitation is that could attain the fact that all our participants had the same sociocultural background. Answering to the question if sociocultural influence before schooling process affects boys and girls semantic organization could be achieved by evaluating children who do not live in urban areas. This will allow the possibility of comparing the performance of two groups exposed to different sociocultural phenomena. If both groups differ from one another as well as between genders, this divergence could be attributed to subject's interaction with the milieu and not to innate basis. The last points noted above remain as questions for further investigation.

\section{Conclusions}

Our study did find differences in a semantic fluency task between genders. However, the bigger question remains open. The relevance of this study relays on the new data added to a long-term discussion in the field of cognitive science: are gender-based differences in semantic processing innate or culture-bounded? In this 
sense, our results do not support either of the theoretical explanations. Moreover, they are somewhat contradictory with previous research on the same topic. The discrepancy of our data could be explained as a result of different variables, including the specific population or the task at hand.

We cannot take a stance for the evolutionary or the context-dependant hypothesis. Further research needs to be carried out in order to explain the diversity in our findings as well as other studies'. Even so, the present paper provides new evidence from a specific age group in a specific population to a current theoretical discussion in the field.

\section{References}

1. Albanese, E., Capitani, E., Barbarotto, R., \& Laiacona, M. (2000). Semantic category dissociations, familiarity and gender. Cortex, 36, 733-746.

2. Barbarotto, R., Laiacona, M., \& Capitani, E. (2008). Does sex influence the age of acquisition of common names? A contrast of different semantic categories. Cortex, 44(9), 1161-1170. doi: http://dx.doi.org/10.1016/j.cortex.2007.08.016

3. Capitani, E., Laiacona, M., \& Barbarotto, R. (1999). Gender affects Word retrieval of certain categories in semantic fluency tasks. Cortex, 35, 273-278. doi: http://dx.doi.org/10.1016/S0010-9452(08)70800-1

4. Capitani, E., Laiacona, M., Mahon, B. Z., \& Caramazza, A. (2003). What are the facts of semantic category-specific deficits? A critical review of the clinical evidence. Cognitive Neuropsychology, 20, 213-261. doi: http://dx.doi.org/10.1080/02643290244000266

5. Caramazza, A., \& Mahon, B. Z. (2003). The organization of conceptual knowledge: The evidence from category-specific semantic deficits. Trends in Cognitive Sciences, 7, 354-361.

6. Caramazza, A., \& Mahon, B. Z. (2006). The organisation of conceptual knowledge in the brain: the future's past and some future directions. Cognitive Neuropsychology, 23, 13-38

7. Caramazza, A., \& Shelton, J. R. (1998). Domain-specific knowledge systems in the brain: The animate-inanimate distinction Journal of Cognitive Neuroscience, 10, 1-34. doi: http://dx.doi.org/10.1162/089892998563752

8. Casals-Coll, M., Sánchez-Benavides, G., Quintana, M., Manero, R. M., Rognoni, T., Calvo, L., \& Peña-Casanova, J. (2013). Estudios normativos españoles en población adulta joven (proyecto NEURONORMA jóvenes): normas para los test de fluencia verbal. Neurología, 28(1), 33-40.

9. Fumagalli, J.; Sorinano, F.; Shalom, D.; Barreyro, J.P; Martinez Cuitiño, M.M (In press). Phonological and semantic verbal fluency task in a sample of Argentinean children. Temas em Psychologia, 25(3).

10.Gainotti, G. (2005). The influence of gender and lesion location on naming disorders for animals, plants and artefacts. Neuropsychologia, 43, 1633-1644. doi: http://dx.doi.org/10.1016/j.neuropsychologia.2005.01.016

11.Gainotti, G., Ciaraffa, F., Silveri, M. C., \& Marra, C. (2010). Different views about the nature of gender-related asymmetries in task based on biological or artefact categories. Behavioural Neurology, 22(3-4), 81-90. doi: http://dx.doi.org/10.1155/2010/410858

12.Gainotti, G., Spinelli, P., Scaricamazza, E., \& Marra, C. (2012). Asymmetries in genderrelated familiarity with different semantic categories. Data from normal adults. Behavioural Neurology, 27(2), 175-181. doi: http://dx.doi.org/10.1155/2013/138646

13.Gerlach, C., \& Gainotti, G. (2016). Gender differences in category-specificity do not reflect innate dispositions. Cortex 85, 46-53.doi: http://dx.doi.org/10.1016/j.cortex.2016.09.022

14.Hurks, P., Vles, J., Hendriksen, J., Kalff, A., Feron, F., Kroes, M., . . . Jolles, J. (2006). Category Fluency Versus Initial Letter Fluency Over 60 Seconds as a Measure of Automatic 
and Controlled Processing in Healthy School-aged Children. Journal of Clinical and Experimental Neuropsychology, 28, 284-295. doi: 10.1080/13803390590954191

15.John, S., \& Rajashekhar, B. (2014). Word retrieval ability on fluency task in typically developing Malayalam-speaking children. Child Neuropsychology: A Journal on Normal and Abnormal Development in Childhood and Adolescence, 20(2), 182-195. doi: http://dx.doi.org/10.1080/09297049.2012.760538

16.Koren, R., Kofman, O., \& Berger, A. (2005). Analysis of word clustering in verbal fluency of school-aged children. Archives of Clinical Neuropsychology, 20, 1087-1104. doi: http://dx.doi.org/10.1016/j.acn.2005.06.012

17.Laiacona, M., Barbarotto, R., \& Capitani, E. (2006). Human evolution and the brain representation of semantic knowledge: Is there a role for sex differences? Evol. Hum. Behav, 27, 158-168. doi: http://dx.doi.org/10.1016/j.evolhumbehav.2005.08.002

18.Laws, K. R. (1999). Gender afects latencies for naming living and nonliving things: implications for familiarity. Cortex, 35, 729-733.

19.Laws, K. R. (2000). Category-specificity naming errors in normal subjects: the influence of evolution and experience. Brain and Language, 75, 123-133. doi: http://dx.doi.org/10.1006/brln.2000.2348

20.Laws, K. R. (2004). Sex differences in lexical size across semantic categories. Personality and invidual differences, 36, 23-32. doi: http://dx.doi.org/10.1016/S0191-8869(03)00048-5

21.Leite, G., Pires, I., Aragão, L., Lemos, P., Gomes, E., Garcia, D., Barros, P., Alencar, J., Fichman, H. \& Oliveira, R. (2016). Performance of Children in Phonemic and Semantic Verbal Fluency Tasks. Psico-USF,21(2), 293-304. https://dx.doi.org/10.1590/141382712016210207

22.Lozano Guitiérrez, A., \& Ostrosky-Solís, F. (2006). Efecto de la edad y la escolaridad en la fluidez verbal semántica: datos normativos en población hispanohablante. Revista Mexicana de Psicología, 23(1), 37-44.

23.Mahon, B. Z., \& Caramazza, A. (2003). Constraining questions about the organization and representation of conceptual knowledge. Cognitive Neuropsychology, 20, 433-450.

24.Marino, J., Acosta Mesas, A., \& Zorza, J. (2011). Control ejecutivo y fluidez verbal en población infantil: medidas cuantitativas,cualitativas y temporales. Interdisciplinaria, 28(2), 245-260.

25.Marino, J., \& Díaz-Fajreldines, H. (2011). Pruebas de fluidez verbal categoriales, fonológicas y gramaticales en la infancia: factores ejecutivos y semánticos. Revista Chilena de Neuropsicología, 6(1), 49-56.

26.Marra, C., Ferraccioli, M., \& Gainotti, G. (2007). Gender-Related Dissociations of Categorical Fluency in Normal Subjects and in Subjects With Alzheimer's Disease. Neuropsychology, 21(2), 207-211. doi: http://dx.doi.org/10.1037/0894-4105.21.2.207

27.Martínez-Cuitiño, M.; Shalóm, D.; Borovinsky, G.; Szenkman, D. \& Fumagalli, J. (2014) ¿Diferencias en el procesamiento semántico en niños en edad escolar? (77). Memorias del VI Congreso Internacional de Investigación y Práctica Profesional en Psicología, XXI Jornadas de Investigación, décimo encuentro de investigadores en Psicología del Mercosur. Adicciones: Desafios y perspectivas para la investigación.

28.McKenna, P., \& Parry, R. (1994). Category-specificity in the naming of natural and man-made objects. Neuropsychological Rehabilitation, 4, 255-281. doi: 10.1080/09602019408401461

29.Moreno-Martínez, F. J., \& Montoro, P. R. (2008). The impact of dementia , age and sex on category fluency: Greater deficits in women with Alzheimer's disease. Cortex, 44,1256-1264.

30.Moreno-Martínez, F. J. \& Moratilla-Pérez, I. (2016). Naming and Categorization in Healthy Participants: Crowded Domains and Blurred Effects of Gender. The Spanish Journal of Psychology 19, 49, 1-15. doi:10.1017/sjp.2016.59 
31.Nieto, A., Galtier, I., Barroso, J., \& Espinosa, G. (2008). Fluencia verbal en niños españoles en edad escolar: estudio normativo piloto y análisis de las estrategias organizativas. Revista de Neurología, 46(1), 2-6.

32. Olabarrieta Landa, L., Benito Sanchez, I., Landa Torre, E., López Mugartza Iriarte, J., Alegret, M., Arango-Lasprilla, J. (2015) The Effect of Specific Language on Performance on Verbal Fluency Tasks in Basque-Spanish Bilinguals. Arch Clin Neuropsychol, 30(6), 565. doi:10.1093/arclin/acv047.208

33.Pekkala, S., Goral, M., Hyun, J., Obler, L. K., Erkinjuntti, T., \& \& Albert, M. (2009). Semantic verbal fluency in two contrasting languages. Clin Linguist Phon., 23(6), 431-445. doihttp://dx.doi.org/10.1080/02699200902839800

34.Riva, D., Nichelli, F., \& Devoti, M. (2000). Developmental Aspects of Verbal Fluency Confrontation Naming in Children. Brain and Language, 71, 267-284. doi: http://dx.doi.org/10.1006/brln.1999.2166

35.Soriano, F., Fumagalli, J., Shalóm, D., Carden, J., Borovinsky, G., Manes, F., \& MartínezCuitiño, M. (2015). Sex differences in a semantic fluency task. East European Journal of Psycholinguistics, 2(1), 134-140.

36.Spreen, O., \& Strauss, E. A. (1998). Compendium of neuropsychological tests (2nd ed.). New York, NY: Oxford Univesity Press.

37.Tulving, E. (1972). Episodic and semantic memory. In E. Tulving \& W. Donaldson (Eds.), Organization Memory. New York: Academic Press. 